\title{
QUASAR COMPANHIA DE DANÇA: EXPRESSÃO DA CONTEMPORANEIDADE EM GOIÁS*
}

\author{
Paula Cristina Peixoto Ribeiro**
}

\section{RESUMO}

Em Goiânia, na década de 1970, a necessidade de questionar e contestar o sistema da época se reflete no corpo que dança. Pede a este novas formas que desafiem o enclausuramento de técnicas clássicas e que expressem o protesto e o desejo de transformações, o que permitirá ao corpo uma liberdade de criação e de expressão. No final da década de 1980, a Quasar Companhia de Dança vem compor uma nova forma estética para o vocabulário da dança goiana. Seu trabalho ficou conhecido mundialmente, apresentando uma estética e uma concepção de dança que nos instiga a conhecê-lo e interpretá-lo.

PALAVRAS-CHAVE: Dança - Arte - Pós-Modernidade - Cultura.

\section{INTRODUÇÃO}

A arte modela a experiência humana, alarga o sistema de significações das coisas, dá forma à relação entre sensibilidade e compreensão. Apreciar e experienciar arte não é apenas uma questão intuitiva e sensorial - arte implica conhecimento.

(Kátia Canton)

\begin{abstract}
A Quasar Companhia de Dança, por ser o que existe de mais A elaborado na dança contemporânea em Goiás, nos move a buscar uma compreensão aprofundada sobre o modo como o corpo que dança irá expressar-se e comunicar-se com o mundo. A companhia obteve reconhecimento internacional como uma das melhores do Brasil, tendo à sua frente um dos melhores coreógrafos do mundo, por coincidência ou não, graduado em Educação Física.
\end{abstract}

\footnotetext{
* Monografia de conclusão do curso de licenciatura em Educação Física da Universidade Federal de Goiás, apresentada em fevereiro de 2003 sob a orientação do Prof. Ms. Ari Lazzarotti Filho e da Prof ${ }^{a}$. Ms.Valéria Figueiredo.

** Licenciada em Educação Física pela Universidade Federal de Goiás.
} 
Para atingir nosso objetivo, buscamos compreender como se manifesta a dança contemporânea na Quasar e, especificamente, analisar sua trajetória e a de seu coreógrafo no contexto histórico da dança goiana, bem como suas influências e os aspectos responsáveis pela linguagem construída na companhia. Procuramos, dessa forma, reconhecer a diversidade de elementos estéticos e a pluralidade de linguagens que a Quasar utiliza para manifestar e revelar sua arte.

Selecionamos para tanto dois espetáculos da companhia, Versus e Divíduo, escolhidos por identificarem dois momentos distintos da Quasar. O espetáculo Versus por ter sido o responsável pela projeção da companhia dentro e fora do Brasil, provocando comentários por suas instigantes e versáteis coreografias. E o espetáculo Divíduo por traduzir, segundo o coreógrafo da Quasar, Henrique Rodovalho, uma nova etapa da companhia, no sentido de um amadurecimento artístico na concepção de toda a obra.

Para realizar este trabalho, de cunho teórico, seguimos alguns passos: a leitura de referências bibliográficas relacionadas com o histórico da dança; o levantamento das veiculações sobre a companhia em jornais e revistas; e a coleta de dados para posterior análise das obras selecionadas, partindo de uma entrevista semi-estruturada com o coreógrafo Henrique Rodovalho e da elaboração de um instrumento de análise para assistir aos espetáculos pelo vídeo. Esse instrumento diferenciado nos possibilitou a construção de categorias de análise com base em Kátia Canton (2001) e Lia Robatto (1994).

\section{DO MOVIMENTO ARTÍSTICO CULTURAL A UMA NOVA PROPOSTA DE DANÇA CONTEMPORÂNEA}

O Movimento Artístico Cultural, surgido em Goiânia nos anos 70, buscava, na expressão corporal, contestar e questionar o sistema vigente, numa época em que se vivia a ditadura militar no Brasil e ecoava no mundo uma necessidade de mudanças e transformações. Nesse momento, abria-se um novo rumo para a dança em Goiânia, que procurava ultrapassar os padrões estabelecidos pelo balé clássico - estilo que predominava nas escolas e academias - e valorizar todas as formas de movimento corporal, ultrapassando limites. 
Esse movimento por uma nova possibilidade de dança teve início na Escola Superior de Educação Física, dentro de uma disciplina chamada Rítmica, que incluía noções básicas de dança e elementos da música, como dinâmica e andamento. Surgia, portanto, uma diversidade de combinações do movimento, o que resultou na formação do Grupo de Dança Univérsica, com influências de outras manifestações artísticas, como o teatro, as artes plásticas, a música, a fotografia, a história da arte e a sociologia da arte. A dança passava a ter um compromisso com a ética, com a estética e com o meio social, negando-se a seguir os passos predeterminados e padronizados, que faziam do espetáculo um mascaramento da realidade, sem conteúdo real e concreto.

Uma nova proposta chega à Goiânia, através de Julson Henrique, "uma das pessoas que mais se destacaram, difundindo e diferenciando a dança em Goiânia, como objeto estético artístico" (Ribeiro, 1998, p. 53), sem o qual seria impossível falar da Quasar. Suas influências foram muitas, tanto para a formação da companhia quanto para a proposta que se iniciou. Ele foi um dos colaboradores da dança contemporânea em Goiânia, conseguindo dar expressividade a essa arte com uma dança diversificada, capaz de dizer algo à sua platéia. De seus trabalhos, saíram Henrique Rodovalho, coreógrafo, e Vera Bicalho, diretora e ex-bailarina do grupo que formou em 1988 a Quasar Companhia de Dança.

A Quasar acreditava em uma dança que pudesse ousar, romper, instigar, expressar a realidade humana, utilizando uma diversidade de elementos que, em vez de comprometer a identidade da dança, ajudassem a passar sua mensagem. Deixava de lado aquela dança que conta historinhas ou representa elementos da natureza para postular uma outra que viesse falar do homem e de sua realidade. E foi isso que a companhia fez de sua dança contemporânea e vanguardista. Buscou uma linguagem própria a partir de experimentações com outras artes, trazendo uma nova forma de usar o corpo para dizer algo e interagindo com vários estilos de movimento, com uma proposta estética que quebrava formas e plasticidades, rompendo com os padrões acadêmicos.

O humor sempre esteve presente na Quasar, que, com um repertório instigante, com a interação de vários tipos de arte e com 
um elenco que mescla movimentos acrobáticos, movimentos gestuais e técnicas interpretativas, estabelece forte relação com a música, numa mistura de dança-teatro. A versatilidade de suas propostas e de seus bailarinos no palco sempre chamou a atenção, pois a Quasar coloca em cena bailarinos caricaturais e exóticos, além de uma movimentação contrastante. Caracteriza-se ainda pela nãopadronização de elenco, de movimentos e de organização coreográfica - o que fica visível, principalmente de um espetáculo para outro -, mostrando sempre a busca de um amadurecimento artístico e o compromisso exclusivo com as questões de nosso tempo.

\section{O CRIADOR E SUA OBRA}

O coreógrafo contemporâneo assume o papel de um ser curioso, absorvendo tudo que o sensibiliza, buscando estar sempre atualizado com as informações de sua época. Mistura e integra vários estilos expressivos e elementos estéticos, sem qualquer obrigação com modelos, desenvolvendo os recursos de composição à sua maneira.

Lia Robatto

Conhecido por revelar talento e criatividade, com uma incrível sintonia de linguagens em seus espetáculos, Henrique Rodovalho é hoje um dos coreógrafos mais originais da dança brasileira. Nascido na década de 1960, em Goiânia, onde vive nos dias atuais, teve seu início na dança de forma um pouco diferente da maioria dos coreógrafos e bailarinos, que iniciavam dentro de uma sala de dança, com caminhos preestabelecidos e estilos a serem seguidos. A sala de dança desse autodidata que começou aos vinte anos, com o corpo já formado, foi a curiosidade, e seu caminho foi o descompromisso com as técnicas e os estilos que lhe eram apresentados. Trouxe para o palco o humor, misturando teatro, mímica e acrobacia e atraindo o público de diversas áreas artísticas.

Seu primeiro contato com a dança foi na Escola de Educação Física do Estado de Goiás (ESEFEGO), através da disciplina Rítmica, e desde então já era perceptível aos professores sua facilidade para lidar com elementos da ginástica olímpica e uma certa intimidade com o movimentar-se. Foi no trabalho final dessa matéria, quando 
os alunos tiveram de realizar uma coreografia, que Henrique teve a primeira sensação de uma idéia coreográfica.

Henrique entrou no grupo de dança da ESEFEGO, onde começou a coreografar. Nesse período passou também, por algum tempo, até mesmo no início da Quasar Companhia de Dança, pela experiência de ser bailarino, mas descobriu que sua verdadeira paixão era coreografar: "até hoje nenhuma coreografia que eu pensei eu me imaginei fazendo" (Rodovalho, 2002). Buscou se aperfeiçoar, freqüentou as aulas de Rainer e Angel Vianna ${ }^{1}$ no Rio de Janeiro, teve algumas experiências no teatro e se interessou pela cinematografia de JacquesTati, Buster Keaton e Charles Chaplin. A linguagem do vídeo lhe chamou a atenção, permitindo-lhe fazer paralelos com a dança contemporânea, no que tange às narrativas linear e não-linear, à quebra e à fragmentação da imagem.

A primeira fase de sua trajetória se estende até o espetáculo Versus, em que suas interferências se davam mais no campo das idéias do que no do movimento propriamente dito. Por não haver tido um contato direto nessa fase com a sala de aula, as suas coreografias não eram criadas e nem imaginadas numa sala de dança, o que acabou contribuindo para um desenvolvimento de concepção, de idéias, com novas possibilidades de dança, mais do que de coreografias baseadas apenas no movimento.

Uma segunda fase é definida a partir do espetáculo Versus. Nesse período, as coreografias passam a ser elaboradas dentro de uma sala de dança, onde começam a experimentar o movimento e a buscar as várias possibilidades deste. O elemento "humor" e a relação música-dança foram criando uma sintonia cada vez maior com o movimento. E os primeiros espetáculos dessa segunda fase resultaram em uma busca de movimentos mais elaborados, ainda enfatizando o elemento "humor". Como o espetáculo Versus acabou se tornando uma referência da transição da primeira para a segunda fase, contém características dos dois momentos. Depois, a partir do espetáculo Registro, segundo Rodovalho (2002) uma tentativa, acima de tudo, de experimentar movimentos, houve um direcionamento mais racional no tocante à concepção e movimentação: tudo era mais pensado do que intuitivo. Isso pode ser visto em Divíduo, em que a movimentação se tornou mais elaborada, mais requintada, e o 
humor sutil. Essas características traduziram também os outros espetáculos, que continuaram valorizando e refletindo uma pós-segunda fase.

A dança contemporânea nesse início de século busca aproximar ao máximo a obra da realidade. Os temas estão cada vez mais relacionados com as situações vividas no cotidiano, proporcionando uma intimidade maior com o público, o que não acontece nos grandes balés, que sempre mantiveram sua platéia intacta. "Rompeu-se, principalmente, o conceito convencional do palco como uma caixa mágica, com a quarta parede separando o público que assistia aos espetáculos, totalmente alheio à realidade da cena" (Robatto, 2002, p. 3). A obra contemporânea trouxe consigo uma série de opções estéticas, utilizando-se de novas tecnologias, como telões e música eletrônica, para acompanhar as tendências do mundo globalizado, o que resultou em um espetáculo de dança onde tudo é permitido. "O Quasar quando está em cena, é como se flertasse com a platéia, convidando-a para uma festa ao mesmo tempo moderna e brasileira" (Katz, 1997, s. p.).

O primeiro espetáculo analisado, Versus, permite-nos explorar a ambigüidade de seu título seja pelo sentido de confronto da palavra, identificado nas diversas situações com que o homem se defronta em seu universo, ou pelo sentido da poesia das músicas de Arnaldo Antunes, que compõem quase toda a trilha sonora. $\mathrm{O}$ espetáculo se divide em 21 pequenas cenas, que possuem a velocidade de um videoclipe, elemento mais explorado nessas coreografias, o que dá a sensação de um grande telão onde passam clipes de nossos cotidianos, combinando cores, movimentos rápidos, iluminação, música e coreografia; ou ainda a sensação de que “o espectador estivesse 'zapeando' um controle remoto de televisão” (Bicalho, 1997, s. p.). As coreografias partem de idéias e imagens que dão origem a movimentos sequienciados, desencadeando pequenas histórias que duram de trinta segundos a quatro minutos, ou seja, brincando com a fragmentação da imagem e do discurso, elementos normalmente proporcionados pelo vídeo, mas que começam a ser visualizados no palco. "Se fazem isso com uma imagem de vídeo, por que não pode ser feito no palco também?" (Rodovalho, 2002). 
Para Vera Bicalho, Versus é uma dissertação sobre a evolução do homem, mostrando situações e contradições dentro do universo cotidiano do ser humano a partir dos aspectos fisiológico, emocional e racional, permitindo especulações e evitando um tom afirmativo. O lado fisiológico pode ser visto a partir de ações que manifestam de uma forma simbólica a necessidade de eliminar impurezas humanas. O emocional destaca a atração primitiva, e o racional é representado por ações que trazem religiosidade e violência, permitindo reflexões diante de certas situações. Essas aparências são traduzidas na linguagem corporal de cada bailarino, com seus corpos habilidosos que mesclam movimentos vigorosos e elegantes e com suas capacidades singulares de expressões faciais e corporais, numa característica bastante forte nesse espetáculo, o humor.

O figurino é fator importante na concepção do espetáculo: é simples e colorido e possui um traço cosmopolita, realçando o homem atual e contribuindo para a irreverência dos bailarinos, que em alguns momentos dançam de saia. A trilha sonora é inspirada nos poemas concretistas de Arnaldo Antunes, do CD Nome, que, por si só, traz o lado provocativo e irreverente. Segundo Henrique, é "a temática da ditadura da identificação" casando com a proposta do espetáculo, que traz como títulos de suas pequenas cenas a letra dos poemas. A poesia de Arnaldo Antunes ainda faz um contraponto com as percussões africanas de Drummers of the Burundi e com as canções de David Byrne, mesclando o lado racional dos poemas com o lado emocional dos tambores, o que resulta numa interação entre o intuitivo e o carnal.

No Brasil, poucos grupos de dança desenvolvem, com a pertinência do Quasar, o trânsito entre a cultura erudita da dança e a música popular brasileira. Poucos como ele se dedicam a construir um corpo que dance com as texturas da urbanidade de nossos tempos. (Katz, 1999, p. 10)

O título do segundo espetáculo analisado, Divíduo, significa aquilo que pode ser separado, dividido, e remete a tudo na obra, desde a divisão do movimento, do corpo, do tempo, das pessoas separadas e isoladas até a divisão do cenário, numa tentativa de provocar a reflexão do homem diante das estruturas fragmentadas 
que permeiam o mundo atual. O espetáculo possui uma unidade no desenvolvimento da proposta: duas cenas, embora isoladas, acontecem ao mesmo tempo, mostram uma continuidade. A concepção coreográfica não se apropria do blecaute, recurso técnico muito utilizado nos trabalhos anteriores para determinar o tempo das coreografias. Nesse espetáculo, o público acompanha todos os passos dos bailarinos, inclusive quando não estão dançando.

Divíduo é a descrição exata do homem dos grandes amontoados urbanos desse início de século. No palco estão os retratos de personagens solitários que vivem enjaulados em suas pequenas residências, em seus cotidianos agonizantes. O espetáculo traz de maneira explícita a relação humana sendo corroída em função do eu social e expressa a dualidade vivenciada no cotidiano real pela divisão dos mundos real e imaginário. "Essa solidão não é pejorativa nem estereotipada. Tem momentos em que as pessoas fazem questão de ser ou estar sozinhas" (Rodovalho, 1999, p. 3).

O espetáculo traz alguns enfoques sobre o homem cada vez mais "independente" e solitário em conseqüência do mundo moderno, um homem que tem a tecnologia como vínculo com o mundo exterior. Destacam-se, por exemplo, a ausência do toque e a presença marcante do olhar perdido e frio, apresentando o homem fragilizado diante do encanto do amor e de coisas comuns, como o contato com o vizinho, que se tornaram raras em um mundo onde internet, televisores, disque-erotismo e pizza substituem qualquer solidão, papo chato e carência afetiva.

Em Divíduo, mesclam-se teatro, pitadas de humor sutil, dança e improvisação. O movimento parte do princípio da divisão do corpo, passando pelo chão e plano médio, combinados entre si. São movimentos localizados, como se as partes do corpo tivessem vida própria, e um movimento levasse a outro.

O cenário do espetáculo divide o palco em quatro ambientes com estruturas metálicas revestidas de fibras de vidro, lembrando cômodos de apartamentos do final do século, com formatos quadrados à semelhança de televisões, e limitados por paredes concretas ou imaginárias, feitas de tijolo e cimento. As paredes destacam a solidão do ser, reforçada pela iluminação intimista. O figurino dos bailarinos são roupas comuns usadas no cotidiano por pessoas que 
seguem um estilo. Utilizam-se calças pantalonas, tênis, blusas e roupa íntima. A trilha sonora do alemão Hendrik Lorezen traz sons variados, como vozes, buzinas, ecos da cidade e depoimentos, conseguindo ser fiel na representação do cotidiano em suas músicas.

\section{ANÁLISE DAS OBRAS}

A análise das obras Versus e Divíduo não tem como intenção classificar ou enquadrar a dança contemporânea. Isso seria uma tentativa de torná-la um estilo codificado, indo contra sua principal característica, a liberdade de expressão. O que buscamos com essa análise é identificar alguns elementos que compõem uma obra de dança contemporânea, tendo em vista compreender suas expressões singular e geral.

Todo um contexto de transformações em que se inscreve o período pós-moderno reflete-se na arte contemporânea, cujas tendências se encontram "mergulhadas numa condição de estranhamento e instabilidade". Segundo Canton (2001), essas transformações se refletem também na dança. Como salienta Robatto (2002), mesmo os bailarinos que optaram por uma postura extemporânea, adotando técnicas retrógradas de preparação corporal, querendo ou não irão incorporar as transformações inerentes à sua época, tanto na sua conformação ou postura física, como na sua interpretação. A dança contemporânea do final do século XX acompanha todo um processo de globalização e de inserção dos meios tecnológicos da sociedade contemporânea, apropriando-se de uma diversidade de elementos para expressar sua arte da melhor forma possível. Para compreender melhor essa dança, a análise das obras baseou-se em seis categorias: narrativa, corpo, identidade/anonimato, ambiente urbano, diversidade estética no movimento e elementos cênicos.

Segundo Canton (2001), o artista contemporâneo busca expressar na arte um sentido, passando uma mensagem que finca seus valores na compreensão e na apreensão da realidade cotidiana. Por meio dessa mensagem, ele tenta estabelecer uma conexão com o observador, provocando e instigando nele algum tipo de reflexão, uma postura diante do mundo e da vida. Essa relação de sentido na 
obra contemporânea acontece a partir de narrativas que permitem várias possibilidades de leitura, ou seja, não são únicas e lineares. O espetáculo Versus, em sua totalidade, traz uma narrativa fragmentada em que as cenas não apresentam um compromisso de organização lógica e simplista do pensamento. Existe uma idéia central que traduz uma dissertação sobre o homem, incorporando várias situações vividas por ele, desde sua evolução e seus potenciais de estranhamento até situações mais diversas e corriqueiras, sem que a narrativa obedeça à seqüência lógica dos fatos.

Uma diversidade de elementos cênicos é utilizada em conjunto com a linguagem gestual, reforçando esses jogos narrativos, como por exemplo o blecaute, a iluminação que em alguns momentos invade uma cena para trazer outra situação, a interpretação gestual satírica dos bailarinos marcada em um cenário abstrato, o figurino que muda os temperamentos do homem, ora racional, ora instintivo. Além disso, as narrativas são manipuladas e dissecadas nas estruturas da poesia de Arnaldo Antunes. Toda essa gama de possibilidades que compõe a narrativa vem dar sentido à obra, "podendo alcançar uma significativa comunicação com espectadores de vários níveis de informação e das mais variadas culturas" (Robatto, 2002, p. 2).

No espetáculo Divíduo, pode ser identificada uma narrativa linear em decorrência de uma unidade que amarra a mensagem do espetáculo do início ao fim. Mensagem esta que aborda a solidão do homem contemporâneo influenciado pela utilização dos meios de comunicação virtual e transformado em um ser frio e marcado pela incapacidade de se comunicar com o outro. Não obstante a linearidade da narrativa, acontecem cenas simultâneas e em espaços diferentes, mas predomina sempre a mesma mensagem.

Um elenco cênico sofisticado de suportes e possibilidades de mecanismos virtuais é valorizado na composição da obra, somando-se a todos esses elementos incorporados uma relação de sentido; ou seja, tudo que compõe a obra possui um significado por si só, reforçando o sentido da narrativa do espetáculo. E para validar ainda mais a mensagem, o coreógrafo leva ao palco bailarinos que agem como pessoas normais em seus cotidianos. Estes utilizam como figurinos roupas do dia-a-dia, falam ao telefone, pedem pizza e assistem à TV. Tudo isso num cenário frio, marcado por paredes de 
concreto, material característico da arquitetura moderna, de modo a reforçar a solidão e a ausência que convivem nesses ambientes.

Um universo de complexidade gira em torno das questões do corpo. Entendendo-o como um reflexo do contexto desse final de século e dos meios de comunicação virtual, tratamos desse novo corpo que se formou também na dança contemporânea, identificando na obra de Henrique Rodovalho as várias faces que ele retrata.

No espetáculo Versus, os corpos dos bailarinos comunicam, através da dança, percepções, sensações, sentimentos, emoções e condicionamentos comportamentais, sendo "depositário de suas vivências". Tecendo comentários sobre sexo, religião, descoberta de si próprio e necessidades fisiológicas, a narrativa ultrapassa a noção de um corpo puramente físico e orgânico para lidar com seu entorno, com os locais que ele habita, com as ausências, os rastros e as inquietações da existência humana, conjugando todas as sensações, formas, emoções, cores e movimentos.

Os bailarinos não apresentam a beleza estética exigida e padronizada para os intérpretes do balé clássico, segundo a qual o bailarino deve ser jovem, alto, esguio e longilíneo. Os corpos fogem desse padrão, com tipos estranhos, exóticos, com mulheres de corpos definidos, musculosos, deixando a expressão de leveza e fragilidade e atingindo um vigor atlético com a mesma carga de agressividade e virilidade própria do homem. "O corpo humano é, indubitavelmente, um material extremamente sensível às realidades de cada época, portanto plástico e flexível" (Robatto, 2002, p. 2).

No espetáculo Divíduo, o corpo retrata a solidão, a identidade e a sexualidade, saindo do âmbito individual e abrangendo uma universalidade assolada por um mundo virtual, globalizado. Os corpos dos bailarinos continuam apresentando uma beleza reformulada, mostrando-se musculosos e definidos tanto para homens quanto para mulheres. Não buscam apresentar um ser estranho, exótico; os bailarinos têm características mais comuns, assemelhando-se a pessoas vistas no cotidiano.

O corpo do artista, nessa obra, se abre e desnuda para o público, trazendo para sua memória corporal rastros das sensações afetivas que se confrontam com tendências do mundo regido por comunicações virtuais. O corpo se torna o principal código de mensagem, 
como pode ser visualizado na primeira cena, em que um casal apresenta uma discussão. Nessa cena é o corpo em movimento que diz o que a boca fala, enquanto outro corpo permanece estático como resposta, o que possibilita uma interpretação plástica e visual.

Noutra cena, em que o corpo reforça a mensagem, utiliza-se o depoimento gravado de pessoas que contam como é fazer certas coisas sozinhas. Apesar de se utilizarem meios de comunicação eletrônica, deixando a narrativa clara naquele momento, é o corpo que vem conjugar o pensamento, interpretar o que o depoimento apresenta. Torna-se possível presenciar no corpo de cada bailarino a sensação real das pessoas que depõem.

Segundo Canton (2001), o artista tenta provocar no seu espectador, através da obra, uma identidade com as questões e inquietações de uma sociedade pós-moderna, fincada em valores individualistas e solitários. Tenta-se mostrar o grau de anonimato em que as relações humanas passam gradativamente a operar.

A utilização, em alguns momentos, das saias como figurino para bailarinos, no espetáculo Versus, reforça satiricamente a busca de si próprio pelo homem, um ser que veio do macaco, que se mostra confuso quanto à sua origem, perguntando-se a que tribo pertence. $\mathrm{O}$ recurso traz à tona o confronto com o outro na busca de identidade e até mesmo a questão do ser assexuado.

No espetáculo Divíduo, essa busca de identidade é visível na cena em que dois bailarinos se olham, mas se estranham e desviam o olhar, não se assumem, dialogam com a parede concreta. Um bailarino liga o rádio, e o outro continua a falar com a parede. Nesse momento os meios de comunicação apresentam recursos de diálogo com o homem solitário.

A obra Versus traz um dos mais comuns retratos contemporâneos do ambiente urbano ao mostrar o comportamento das pessoas dominadas pelo tempo, pelo individualismo e pela violência. Essas características predominantes na sociedade moderna podem ser identificadas nas cenas de uma forma bem-humorada e plástica, na movimentação e interpretação dos bailarinos.

Em determinadas cenas, predomina o ambiente urbano, através da retratação do homem que vive em função do tempo, cobrado pelo relógio, buscando uma regularidade e uma suposta 
organização em sua vida, de acordo com padrões de horários preestabelecidos. Um exemplo pode ser percebido na coreografia FÊNIS, que utiliza toda a plasticidade do movimento e da música cujo som é o de uma respiração forte e ofegante para legitimar o sentido da violência anestesiado nas grandes cidades. A coreografia mostra uma briga entre duas bailarinas, que reforçam a cena utilizando uma arma.

Na obra Divíduo, o cotidiano nas grandes cidades se coloca como pano de fundo para tratar a solidão e a incomunicabilidade gerada pelos avanços tecnológicos dos meios de comunicação virtual que permeiam as relações humanas. Um dos focos desse ambiente urbano é mostrado por meio de uma cena corriqueira: um bailarino pedindo uma pizza por telefone.

Outra cena, em que um bailarino dança fora do teatro, é transmitida simultaneamente em um telão para dentro do teatro, e ao mesmo tempo uma bailarina dança no palco a mesma coreografia. Essa cena faz um diálogo entre o real e o virtual: para acentuar ainda mais essa relação com o espaço frio, calculista, aprisionado por prédios, carros e pessoas indiferentes e desenfreadas pelas calçadas, mostra-se o homem que perde sua relação com a natureza e passa a ocupar o ambiente urbano.

As relações entre o espaço real e o virtual, conseqüência do uso da informática no cotidiano da vida moderna, provocaram uma mudança radical na gramática da dança, rearrumando todo o sistema de trabalho de mis-en-place no palco e ampliando as possibilidades criativas de encenação no processo da composição dos elementos coreográficos. Paralelamente os atuais conceitos do espaço contextualizado estenderam o palco e as suas funções para seu entorno arquitetônico ou social. (Robatto, 2002, p. 2)

A diversidade estética no movimento, pela pluralidade de técnicas que integra, concede ao vocabulário contemporâneo uma plasticidade que lhe permite passar sua mensagem da melhor forma possível. Em decorrência dessa diversidade, o movimento não segue uma rigidez de formas e vem superar e explorar os limites do corpo, do espaço e da liberdade de criação. De acordo com Robatto 
(1994), o movimento na obra Versus é um meio, trazendo na sua plasticidade a idéia a ser passada e um fim, apresentado como uma obra estética.

Nessa obra podemos identificar um intercâmbio de linguagens corporais com formas de movimentos de vários estilos, como a irreverência teatral. Ela oferece um humor escrachado, gestos, uma movimentação acrobática que lembra artistas circenses, expressão corporal, mímica e movimentos atléticos. Essa mescla de linguagens que resultam numa movimentação inusitada é visualizada em toda a obra, mas a movimentação gestual é predominante na maioria das cenas, reforçando o elemento "humor", característica intrínseca da Quasar.

A coreografia DOIS faz um diálogo entre os corpos feminino e masculino sobre um tablado, sem o elemento "humor". O movimento mostra corpos sedutores que, ao som de uma percussão africana, mesclam o virtuosismo da técnica clássica com a expressão corporal, movimentando-se na meia-ponta. Essa técnica consiste em não encostar os calcanhares no chão e em manter, com os segmentos do corpo, linhas características do balé clássico, contrapondo com rolamentos e quebras-de-tronco. As pegadas podem ser bastante visualizadas nessa cena, em que os corpos se encontram e se enroscam quando os dois bailarinos estão no chão ou quando um está no ar, dando a impressão de um corpo só. O movimento ganha formas plásticas, numa mensagem estética subjetiva que representa uma idéia irracional, instintiva do homem, e ao mesmo tempo contida e contemplativa.

Na obra Divíduo, pode ser identificado um forte conteúdo estético expressivo e interpretativo do atual contexto em que se insere o homem e suas relações. A plasticidade advinda da movimentação vem retratar de forma consistente o enclausuramento propiciado pelo ambiente urbano. Os movimentos acrobáticos e de risco deixam de predominar na movimentação, que se amplia na exploração de cada segmento do corpo ao máximo, tornando-se detalhista e requintada. As partes do corpo têm vida própria, com movimentos localizados em que um segmento leva o outro, mas não numa sequiência lógica. Por exemplo, a mão leva o braço, que leva o tronco e depois a cabeça, mas não para a mesma direção ou numa mes- 
ma seqüência. Os bailarinos exercem no palco ações do cotidiano, utilizando os gestos e a fala e ainda a caracterização dos elementos cênicos. Isso proporciona uma definição mais real de personagens e dessas ações, além de propiciar uma plasticidade autêntica e de uma "estranheza estimulante".

Essa plasticidade permite uma comparação. O espaço do palco no balé clássico concede o centro para um casal, a solista e seu partner, sempre numa ação virtuosa de um encontro amoroso. E o que vemos em Divíduo é a ousadia da dança contemporânea de apresentar nesse centro uma parede concreta que divide um casal. Os componentes desse casal não são os principais da ação, mas os que compartilham com o elemento cênico a mesma carga de sentido real da mensagem a ser transmitida.

Em outra cena, a plasticidade dos corpos em movimento vem detectar o relacionamento homem-mulher sem a presença do toque. Os corpos se cruzam numa movimentação acrobática e delineada no chão e plano médio, mas em momento algum se verifica qualquer contato. São movidos por pergunta e resposta como num jogo de capoeira. E a música, mesclando elementos de capoeira com um tema que fala de amor, possibilita movimentos que reforçam a solidão nos relacionamentos.

Hoje em dia não se admite um trabalho de dança levianamente improvisado, criativo porém caótico, original porém mal acabado. As atuais propostas coreográficas buscam movimentos mais naturais porém contundentes, agudos e altamente requintados nos detalhes, delineados no espaço com perfeita definição formal, controle rítmico e técnico. Essa recente estética da dança cênica requer intérpretes com uma liberdade de movimentos aliada a um domínio técnico corporal de qualidade. (Robatto, 2002, p. 3)

Nesse final de século, um amplo repertório de possibilidades de elementos cênicos foi instaurado na dança contemporânea, buscando sentidos que se infiltram na realidade do mundo contemporâneo. Estreitou-se a distância entre arte e tecnologia, e a produção artística apropriou-se dos recursos tecnológicos e virtuais, valendo-se de tudo para passar sua mensagem. Perderam-se assim os limites que 
delimitavam o universo artístico. Ao analisar os elementos cênicos nas obras da Quasar - espaço, figurino, luz, objetos, painéis, música, recurso tecnológico, multimídia - verificamos que eles propiciam uma dança com características mais realistas e interpretativas.

No espetáculo Versus, o coreógrafo utiliza vários elementos cênicos para expressar sua idéia de forma singular e original. O cenário é abstrato, e alguns objetos são utilizados em determinados momentos para delimitar a ação, como a cadeira na cena do início e do final. Na coreografia TRÊSS, reforçando seus movimentos acrobáticos, os bailarinos saltam, giram e rolam com cadeiras que assumem uma função de plasticidade no movimento e pelo tablado, numa subjetiva disputa individual, marcando seu espaço. O tablado apresenta o desenho de um homem nu, lembrando os desenhos e estudos de Leonardo da Vinci sobre a anatomia humana e construindo um espaço com função visual e plástica. Esse tablado se desloca, pela ação dos bailarinos, durante algumas cenas, sendo utilizado nas coreografias em que as percussões africanas estão presentes, de modo a trazer uma subjetividade do homem instintivo. Também se utilizam como elemento visual tatuagens pintadas nos corpos de todos os bailarinos, criando no espectador um percurso visual, independente da fragmentação da narrativa. A iluminação é outro recurso muito empregado, ajudando na delimitação dos espaços e da narrativa.

Uma música ou um cenário não tem mais só valor decorativo ou ilusório de ambientação cênica, mas o valor da mensagem estética válida por si própria, exposto em contraponto com a ação cênica, teatral ou coreográfica. (Robatto, 1994, p. 289)

As poesias concretistas de Arnaldo Antunes e as percussões de Burundi utilizadas na obra são elementos sonoros determinantes tanto na mensagem da narrativa quanto na plasticidade dos movimentos. O figurino usado pelos bailarinos apresenta traços de uma cultura cosmopolita, sem exageros ornamentais. Esse figurino vem reforçar as características intrínsecas da Quasar, como o humor e a ambigüidade, no caso dos homens, em alguns momentos, de saia.

No espetáculo Divíduo utiliza-se também como recurso cênico a diversidade dos elementos eletrônicos, como rádio, TV, telefone, 
máquina fotográfica, fotografia, telão e multimídia, elementos estes que marcam as relações do homem no cotidiano contemporâneo. Isso pode ser visto na cena final, que mostra um bailarino fora do espaço cênico do espetáculo, inserido agora no espaço urbano, criando um diálogo entre o real e o virtual - a cena é apresentada ao público através de um telão.

O cenário apresentado na obra reforça o aspecto do homem no ambiente, sua solidão. As paredes de concreto instaladas no espaço cênico, subdividindo-o, criam uma atmosfera individualista característica da nossa sociedade atual. Os objetos inseridos nesse contexto lembram essa ausência e incomunicabilidade com o outro. Os figurinos utilizados na obra são roupas do cotidiano que representam um perfil e um estilo de vida, como tênis, pantalonas, blusinhas, mochilas e outros.

\section{CONCLUSÕES}

Podemos perceber, pela análise das duas obras, a pluralidade de linguagens e elementos estéticos rompendo o tradicional, e uma valorização do presente. É possível visualizar uma instabilidade nas características de sua movimentação. Não existe uma preocupação em manter uma linha de movimento entre os dois espetáculos. $\mathrm{O}$ fato de pertencerem ambos à mesma companhia causa uma certa confusão, pois, embora um e outro sejam obras artísticas de qualidade, são completamente diferentes em sua movimentação, concepção cênica e narrativa.

Não seria possível estabelecer padrões entre eles. O que podemos constatar são as diversas formas que essa dança irá manifestar - através de sua forma, plasticidade, narrativa e identidade e dos seus elementos cênicos - nas obras de um mesmo grupo, não se conformando em seguir sempre um mesmo caminho para expressar sua arte. Aí está o fascínio da dança contemporânea: a diversidade de possibilidades que permite não só ao corpo que dança, mas a tudo que irá compor essa dança, transpor qualquer regra e limite.

As obras trazem uma preocupação com a fragmentação e um excesso de informações, linguagens e movimentos que às vezes satura. E é esse o objetivo. Os elementos estéticos falam por si só, 
apresentam uma narrativa que desconstrói ou resultam em jogos narrativos, deixando em aberto sua ambigüidade. As relações entre espaço real e virtual, com a utilizacão de multimídia e a participação de pessoas anônimas, enfatizam o processo urbano como algo incontrolável em que situações acontecem ao acaso. Isso causa um certo transtorno ao pensamento da obra, na medida em que se confundem o real e o imaginário.

Identificamos, também, algumas caracterísiticas da condição pós-moderna que norteiam uma virada estética na arte e conseqüentemente na dança, principalmente na dança goiana, de que estamos falando. Segundo David Harvey (1989), a pós-modernidade se configura em uma nova estrutura de sentimento, causando uma confusão quanto ao que poderia envolvê-la. Ela traz uma total aceitação do efêmero, do fragmentário, do instável, do ambíguo, do descontínuo e do caótico, respondendo a tudo isso de uma maneira singular. O retrato do pós-modernismo depende de um modo particular de experimentar, interpretar e ser no mundo. A pósmodernidade não busca transcender, opor ou definir elementos que poderiam estar contidos nela como eternos e imutáveis. E a inserção de jogos de linguagem feita por ela vem sugerir um conjunto distinto de códigos e uma heterogeneidade de elementos.

A partir desses pontos que identificam uma condição pósmoderna podemos fazer uma análise da dança em Goiânia. Tendo se iniciado nessa cidade fora dos padrões do balé clássico, ela surge, a princípio, questionando o sistema vigente com sua liberdade de criação, mas sem apresentar ainda características pós-modernas. Ao contrário, as características modernistas, como o transcender e o opor, ainda estão presentes. A dança contemporânea pós-moderna só chega a Goiás com a proposta da Quasar Companhia de Dança, causando uma certa anarquia. Seus integrantes são atraídos pela quebra, ironia, desconstrução, ambigüidade e combinação, sem buscar transcender ou opor. O que ocorre é uma constante busca de amadurecimento artístico que abre possibilidades, permitindo uma maior clareza e consciência da proposta a cada espetáculo, direcionando-a aos rumos pós-modernos e angariando-lhe características próprias. 


\title{
Quasar Dance Company: \\ the Expression of Modernity in Goias
}

\begin{abstract}
The need for questioning and challenging the system in Goiânia in the 1970s is reflected in the dancing body. The body is asked to seek new forms of movement that challenge the imprisonment imposed by classic techniques and that express protest and the desire for change, giving the body freedom of expression and of creation. At the end of the 1980s, Quasar Dance Company started to compose a new aesthetic form to the vocabulary of dance in Goias. Their way of dancing became known worldwide, as it presented a provoking conception and aesthetics of dance that leads us into knowing it and interpreting it.

KEY WORDS: Dance - Art - Post-Modernity - Culture.
\end{abstract}

\section{Quasar Compañía de Danza: Expresión de la Contemporaneidad en Goiás}

\section{RESUMEN}

En Goiânia, en la década de 70, la necesidad de cuestionar y contestar el sistema de la época se refleja en el cuerpo que danza. Pide a este nuevas formas que desafían el cierre de técnicas clásicas y que expresen la protesta y las ganas por transformaciones, que permitió al cuerpo una libertad de creación y de expresión. Al final de la década de 80, Quasar Compañía de Danza compone una nueva forma estética al vocabulario de la danza goiana. Su danza quedó conocida mundialmente, presentando una estética y una concepción de danza que nos instiga a conocerla e interpretarla.

PALABRAS CLAVES: Danza - Arte - Pos-Modernidad - Cultura.

\section{NOTA}

1 Rainer e Angel Viana foram professores que abriram novas perspectivas para os artistas da dança brasileira, com seus conhecimentos avançados sobre consciência corporal.

\section{REFERÊNCIAS}

BICALHO, Vera. Versus tem a velocidade de um videoclipe. Jornal do Estado, Curitiba, 5 ago. 1997.

CANTON, Kátia. Novíssima arte brasileira: um guia de tendências. São Paulo: Iluminuras, 2001. 198 p.

HARVEY, David. Condição pós-moderna. São Paulo: Loyola, 1989. 349 p. 
KATZ, Helena. Uma festa moderna e brasileira. O Jornal, Maceió, 12 ago. 1997. Variedades.

KATZ, Helena. Quasar Cia. de Dança mostra Divíduo. Diário da Manhã, Goiânia, 11 dez. 1999.

RIBEIRO, Luciana. Dança contemporânea em Goiânia: o começo de uma história. 1998. Monografia de Conclusão de Curso (Graduação em Educação Física). Escola Superior de Educação Física do Estado de Goiás, Goiânia, 1998.

ROBATTO, Lia. Dança em processo: a linguagem do indizível. Salvador: Centro Editorial e Didático da UFBA, 1994. 349 p.

ROBATTO, Lia. Um olhar sobre a cultura brasileira - dança. Ministério da Cultura. Disponível em: <http://www.minc.gov.br/textos/olhar/danca.htm> Acesso em: 8 set. 2002.

RODOVAlHO, Henrique. A dança da solidão. Gazeta do Povo, Curitiba, 11 nov. 1999.

RODOVALHO, Henrique. Entrevista. Goiânia, 25 out. 2002.

Recebido: maio de 2003 Aprovado: junho de 2003

Endereço para correspondência Paula Cristina Peixoto Ribeiro Rua Arraias, $\mathrm{n}^{\circ} 27$ Conjunto Castelo Branco Cidade Jardim Goiânia-GO. E-mail: paulinhapeixoto@hotmail.com 